\title{
Effect of Panchagavya on Growth and Yield of Organic Blackgram [Vigna mungo (L.) Hepper]
}

\author{
Gopal Lal Choudhary ${ }^{*}$, S.K. Sharma ${ }^{1}$, Kendra Pal Singh ${ }^{1}$, \\ Sanju Choudhary ${ }^{2}$ and B.R. Bazaya ${ }^{3}$ \\ ${ }^{1}$ Department of Agronomy, Rajasthan College of Agriculture, MPUA\&T, Udaipur- 313001, India \\ ${ }^{2}$ Department of Agronomy, S.K.N. College of Agriculture, SKNAU, Jobner- 303329, India \\ ${ }^{3}$ Division of Agronomy, Faculty of Agriculture, SKUAST, Jammu- 180009, India \\ *Corresponding author
}

\section{A B S T R A C T}

\begin{tabular}{|l|}
\hline K e y w o r d s \\
Organic blackgram, \\
Panchagavya, Dry \\
matter, Seed yield, \\
Straw yield, \\
Economics. \\
\hline Article Info \\
\hline $\begin{array}{l}\text { Accepted: } \\
\text { 14 September } 2017 \\
\text { Available Online: } \\
\text { 10 October } 2017\end{array}$ \\
\hline
\end{tabular}

A field experiment was conducted at the instructional farm of Rajasthan College of Agriculture, Udaipur, Rajasthan during kharif season of 2015 to study the effect of panchagavya on growth and yield of organic blackgram. The result indicate that application of panchagavya $4 \%$ recorded significantly maximum dry matter $(7.20 \mathrm{~g}$ plant $\left.^{-1}\right)$, leaf area index (1.92), number of pods (27.42 plant $\left.^{-1}\right)$, number of seeds $(6.78$ pod $\left.^{-1}\right)$, test weight (38.46 g) seed yield $\left(801 \mathrm{~kg} \mathrm{ha}^{-1}\right)$, straw yield (1735 kg ha $\left.{ }^{-1}\right)$, biological yield $\left(2536 \mathrm{~kg} \mathrm{ha}^{-1}\right)$, gross return ( $₹ 89642 \mathrm{ha}^{-1}$ ), net return ( $₹ 67042 \mathrm{ha}^{-1}$ ) and B:C ratio (2.96), respectively over rest of the treatments. Results further reveal that plant height $(32.25 \mathrm{~cm})$, dry matter $\left(6.92 \mathrm{~g} \mathrm{plant}^{-1}\right)$, leaf area index $(1.76)$, number of pods $\left(25.23\right.$ plant $^{-}$ $\left.{ }^{1}\right)$, number of seeds $\left(6.12 \mathrm{pod}^{-1}\right)$, seed yield $\left(751 \mathrm{~kg} \mathrm{ha}^{-1}\right)$, straw yield $\left(1617 \mathrm{~kg} \mathrm{ha}^{-1}\right)$, biological yield $\left(2368 \mathrm{~kg} \mathrm{ha}^{-1}\right)$, gross return $\left(₹ 84021 \mathrm{ha}^{-1}\right)$, net return $\left(₹ 60977 \mathrm{ha}^{-1}\right)$ and $\mathrm{B}: \mathrm{C}$ ratio (2.64), blackgram was observed significantly highest with the application of panchagavya at both branching + flowering stages as compared to either application at branching or flowering branching and flowering stage.

\section{Introduction}

Blackgram is one of the most important pulse crop of India and it contributes $10 \%$ to the total pulse production in the country. It is mainly grown in Madhya Pradesh, Uttar Pradesh, Andhra Pradesh, Maharashtra and Rajasthan. Total area of blackgram in India is 3.26 million hectares with an annual production of 1.76 million tonnes and productivity $555 \mathrm{~kg} \mathrm{ha}^{-1}$ during year 2015 (IIPR, 2015). The food values of blackgram lie in its high and easily digestible protein. Its seed contains approximately $25-28 \%$ protein,
$1.0-1.5 \%$ oil, $3.5-4.5 \%$ fiber, $4.5-5.5 \%$ ash and $62-65 \%$ carbohydrates on dry weight basis. It is also reported to be rich in vitamins A, B and $\mathrm{B}_{3}$ (Sharma et al., 2011). Imbalanced use of chemicals and second generation problems of green revolution in agriculture has weakened the ecological base in addition to degradation of soil, water resources and quality of the food. An awareness has sprung on the adoption of organic farming as an alternate to modern chemical agriculture (Kannaiyan, 2000). 
Pulses are important components of organic farming systems in the country. In recent years, the use of fermented cow dung, cow urine, cow ghee, cow curd and cow milk with the name of panchagavya is getting adaptive popularity in Indian agriculture largely through the efforts of small groups of farmers. Panchagavya has got reference in the scripts of Vedas (divine scripts of Indian wisdom) and Vrikshayurveda (Natarajan, 2002). Panchagavya, an organic product has potential to play the role in promoting growth and providing immunity in plant system. The use of panchagavya results in higher growth, yield, and quality of crops (Choudhary et al., 2014).

\section{Materials and Methods}

A field experiments was conducted during kharif, 2015 at Instructional Farm, Rajasthan College of Agriculture, situated in agroclimatic zone IV a (Sub-humid southern plain and Aravali Hills) of Rajasthan. The region has a semi-arid climate.

The soil of the experimental site was clay loam in texture with $\mathrm{pH} 7.6$ and 0.58 per cent organic carbon. The experiment of was laid out in factorial randomized block design with three replications and assigning 21 treatment combinations consisting of control, comprising six doses of panchagavya (panchagavya 2\%, panchagavya $4 \%$, panchagavya $6 \%$, panchagavya $8 \%$, panchagavya $10 \%$ and indigenous panchagavya $2 \%$ ) as growth promoter and three stages of application of panchagavya (branching, flowering and branching + flowering).

The blackgram variety PU-31 was sown on $9^{\text {th }}$ July 2015 at $30 \mathrm{~cm}$ row to row spacing by using recommended seed rate of $16 \mathrm{~kg} \mathrm{ha}^{-1}$. All other agronomic practices were adopted as per need of the crop.

\section{Results and Discussion}

\section{Effect on growth attributes}

At harvest, application of panchagavya $4 \%$ gave the maximum plant height $(35.89 \mathrm{~cm})$ and recorded a significant increase of 32.93 , $20.36,8.66,14.88,16.26$ and 8.96 per cent in plant height of blackgram over the control, $2 \%, 6 \%, 8 \%$ and $10 \%$ panchagavya and indigenous panchagavya $2 \%$, respectively. Effect of indigenous panchagavya $2 \%$ on plant height of blackgram at harvest was significant over control but it was found at par with 2\% panchagavya (Table 1). Application of panchagavya $4 \%$ gave significantly higher dry matter accumulation $\left(7.20 \mathrm{~g} \mathrm{plant}^{-1)}\right.$ of blackgram and recorded an increase in dry matter accumulation of blackgram at harvest to the tune of $14.47,10.43,6.67,8.27,9.76$ and 10.60 per cent over the control, $2 \%, 6 \%$, $8 \%$ and $10 \%$ panchagavya and indigenous panchagavya 2\%, respectively. Data presented in Table 1 show that application of panchagavya $4 \%$ increase maximum leaf area index (1.76) of blackgram and recorded significantly increased 29.93, 23.08, 17.89, 20.00, 21.52 and 24.68 per cent at 45 DAS increase of leaf area index of blackgram was observed over control, 2\%, 6\%, $8 \%$ and $10 \%$ panchagavya and indigenous panchagavya $2 \%$, respectively. Results further reveal that growth attributes of blackgram viz., plant height $(35.89 \mathrm{~cm})$, dry matter plant ${ }^{-1}(7.20 \mathrm{~g}$ plant $^{-1}$ ) and leaf area index (1.92) were observed significantly heighest with the application of panchagavya at branching + flowering stages as compared to branching alone and flowering. However, application of panchagavya at branching alone and flowering alone was found to be at par with each other in all cases.

Scorching was observed in the leaves at higher concentrations $(6 \%, 8 \%$ and $10 \%$ panchagavya) which might have resulted in 
decreased rate of photosynthetic activity which ultimately resulted in reduction in growth of blackgram at higher concentration of panchagavya. Similar findings were also observed in blackgram by Somasudaram et al., 2003, in Coleus forskohili by Kanimozhi, 2004 and in Abelmoschus esculents by Rajesh and Kaliyamoorthy, 2013). Panchagavya contains N, P, K, S, Fe and Zn. Thus, balanced nutrition might have resulted in better development and robust growth. Panchagavya is also known to contain beneficial micro-organisms such as Azospirillum, Azotobactor, Phosphobacteria and Pseudomonas besides Lactobacillus (Yadav and Lourduraj, 2006) which promotes the plant growth parameters. Besides these, growth regulatory substances such as Indole acetic acid, gibberellic acid and cytokinin have also been reported in panchagavya (Perumal et al., 2006) which resulted in improved plant height, LAI and dry matter accumulation of blackgram. The results of the present study are also in line with Emily (2003) who reported that in Withania somnifera (L.) Duna, the plant height, dry matter production and leaf area index increased significantly due to spraying panchagavya $4 \%$.

The application of panchagavya either at branching or flowering may not supply nutrients in sufficient amount for full development of the plants. Hence, higher plant height, dry matter plant ${ }^{-1}$ and leaf area index were observed with the application of panchagavya at branching + flowering stages of blackgram. Similar findings were also reported by Kumawat et al., (2009).

\section{Effect on yield attributes and yield}

The data presented in Table 2 show that application of panchagavya $4 \%$ gave higher seed yield $\left(801 \mathrm{~kg} \mathrm{ha}^{-1}\right)$, straw yield $(1735 \mathrm{~kg}$ $\left.\mathrm{ha}^{-1}\right)$, biological yield $\left(2536 \mathrm{~kg} \mathrm{ha}^{-1}\right)$ of blackgram over the control, $2 \%, 6 \%, 8 \%$ and $10 \%$ panchagavya and indigenous panchagavya $2 \%$. Further, the data (Table 2) indicate that application of panchagavya at branching + flowering stages recorded the highest seed yield $\left(751 \mathrm{~kg} \mathrm{ha}^{-1}\right)$, straw yield $\left(1617 \mathrm{~kg} \mathrm{ha}^{-1}\right)$, biological yield $\left(2368 \mathrm{~kg} \mathrm{ha}^{-1}\right)$ of blackgram over the application of panchagavya at branching and flowering. The easy transfer of nutrients and growth stimulants to plants through foliar spray of optimum dose of panchagavya might be the reason for enhancement in yield attributes. There are several reasons for increased yield in blackgram due to spray of panchagavya. Smaller quantities of IAA and GA present in panchagavya when foliar sprayed could have created stimuli in the plant system which in turn increased the production of growth regulator in cell system and the action of growth regulators in plant system stimulated the necessary growth and development, leading to better yield. This might be due to favorable effect of panchagavya on vegetative growth viz., number of branches plant ${ }^{-1}$ and reproductive growth viz., pods plant ${ }^{-1}$, seeds pod $^{-1}$ and test weight, which were the important yield attributes having significant positive correlation with seed \& straw yield.

These findings are in the line with those reported by Somasundaram et al., (2003), Somasundaram et al., (2007), Kumawat et al., (2009) and Mudigoudra et al., (2009). The pronounced increase in yield might be due to sustained availability of nutrients $(\mathrm{N}, \mathrm{P}, \mathrm{K}, \mathrm{S}$, $\mathrm{Zn}$ and $\mathrm{Fe}$ ) at growth phases of blackgram and also due to enhanced carbohydrate synthesis and effective translocation of photosynthates to the developing sink. Panchagavya increased synthesis of growth promoting substances which is turn helped in increased growth and yield attributes and finally grain yield. Similarly findings have been reported by Swaminathan et al., (2007) and Choudhary et al., (2014). 
Table.1 Effect of doses of panchagavya and its stage of application on growth and yield attributes of organic blackgram

\begin{tabular}{|c|c|c|c|c|c|c|}
\hline Treatments & $\begin{array}{l}\text { Plant height } \\
(\mathrm{cm})\end{array}$ & $\begin{array}{c}\text { Dry matter } \\
\left(\text { g plant }^{-1}\right)\end{array}$ & $\begin{array}{l}\text { Leaf area } \\
\text { index }\end{array}$ & $\begin{array}{c}\text { Number of pods } \\
\text { plant }^{-1}\end{array}$ & $\begin{array}{c}\text { Number of seeds } \\
\text { pod }^{-1}\end{array}$ & Test weight (g) \\
\hline \multicolumn{7}{|l|}{ Doses of panchagavya } \\
\hline Control & 27.00 & 6.29 & 1.48 & 19.11 & 5.32 & 33.58 \\
\hline Panchagavya $2 \%$ & 29.82 & 6.52 & 1.56 & 23.54 & 5.51 & 34.75 \\
\hline Panchagavya $4 \%$ & 35.89 & 7.20 & 1.92 & 27.42 & 6.78 & 38.46 \\
\hline Panchagavya $6 \%$ & 33.03 & 6.75 & 1.63 & 24.99 & 6.11 & 35.97 \\
\hline Panchagavya $8 \%$ & 31.24 & 6.65 & 1.60 & 24.66 & 5.80 & 35.86 \\
\hline Panchagavya $10 \%$ & 30.87 & 6.56 & 1.58 & 23.99 & 5.73 & 35.41 \\
\hline Indigenous panchagavya $2 \%$ & 29.58 & 6.51 & 1.54 & 23.33 & 5.47 & 34.88 \\
\hline SEm \pm & 0.50 & 0.14 & 0.07 & 0.50 & 0.18 & 0.74 \\
\hline C.D. $5 \%$ & 1.44 & 0.39 & 0.20 & 1.42 & 0.52 & 2.11 \\
\hline \multicolumn{7}{|c|}{ Stage of panchagavya application } \\
\hline Branching & 30.56 & 6.55 & 1.57 & 22.86 & 5.64 & 34.63 \\
\hline Flowering & 30.38 & 6.45 & 1.52 & 23.50 & 5.69 & 34.96 \\
\hline Branching + Flowering & 32.25 & 6.92 & 1.76 & 25.23 & 6.12 & 37.09 \\
\hline SEm \pm & 0.33 & 0.09 & 0.05 & 0.33 & 0.12 & 0.48 \\
\hline C.D. $5 \%$ & 0.94 & 0.26 & 0.13 & 0.93 & 0.34 & 1.38 \\
\hline
\end{tabular}

Table. 2 Effect of doses of panchagavya and its stage of application on yield and economics of organic blackgram

\begin{tabular}{|c|c|c|c|c|c|c|c|}
\hline \multirow{2}{*}{ Treatments } & \multicolumn{3}{|c|}{ Yield $\left(\mathrm{kg} \mathrm{ha}^{-1}\right)$} & \multirow{2}{*}{$\begin{array}{c}\text { Harvest index } \\
(\%)\end{array}$} & \multirow{2}{*}{$\begin{array}{l}\text { Gross return } \\
\left(₹_{\text {ha }^{-1}}\right)\end{array}$} & \multirow{2}{*}{$\begin{array}{l}\text { Net return } \\
\left(₹_{\text {ha }^{-1}}\right)\end{array}$} & \multirow[t]{2}{*}{ B:C ratio } \\
\hline & Seed & Straw & Biological & & & & \\
\hline \multicolumn{8}{|l|}{ Doses of panchagavya } \\
\hline Control & 519 & 1272 & 1791 & 29 & 58918 & 36918 & 1.68 \\
\hline Panchagavya $2 \%$ & 686 & 1512 & 2198 & 31 & 76914 & 54614 & 2.45 \\
\hline Panchagavya $4 \%$ & 801 & 1735 & 2536 & 32 & 89642 & 67042 & 2.96 \\
\hline Panchagavya $6 \%$ & 715 & 1534 & 2249 & 32 & 79926 & 57026 & 2.49 \\
\hline Panchagavya $8 \%$ & 697 & 1519 & 2217 & 32 & 78068 & 54868 & 2.36 \\
\hline Panchagavya $10 \%$ & 690 & 1505 & 2195 & 32 & 77322 & 53822 & 2.29 \\
\hline Indigenouspanchagavya $2 \%$ & 681 & 1512 & 2193 & 31 & 76448 & 54073 & 2.42 \\
\hline $\mathrm{SEm} \pm$ & 20 & 59 & 68 & 1 & 2121 & 2121 & 0.09 \\
\hline C.D. $5 \%$ & 57 & 168 & 193 & NS & 6063 & 6063 & 0.27 \\
\hline \multicolumn{8}{|c|}{ Stage of panchagavya application } \\
\hline Branching & 635 & 1470 & 2105 & 30 & 71581 & 49116 & 2.19 \\
\hline Flowering & 667 & 1451 & 2118 & 31 & 74643 & 52063 & 2.30 \\
\hline Branching + Flowering & 751 & 1617 & 2368 & 32 & 84021 & 60977 & 2.64 \\
\hline SEm \pm & 13 & 38 & 44 & 1 & 1389 & 1389 & 0.06 \\
\hline C.D.5\% & 37 & 110 & 127 & NS & 3969 & 3969 & 0.18 \\
\hline
\end{tabular}




\section{Economics of the treatments}

The data presented in Table 2 show that application of panchagavya $4 \%$ increased the gross return ( $₹ 89642 \mathrm{ha}^{-1}$ ), net return ( ₹ $67042 \mathrm{ha}^{-1}$ ) and B:C (2.96) ratio of blackgram as compared to control and other doses of panchagavya. Results further reveal that maximum gross return ( $₹ 84021 \mathrm{ha}^{-1}$ ), net return ( $₹ 60,977 \mathrm{ha}^{-1}$ ) and $\mathrm{B}: \mathrm{C}$ (2.64) ratio blackgram was observed with the application of panchagavya at both branching + flowering stages as compared to either application at branching or flowering branching and flowering stage. The increased net return could be explained on the basis of increased seed $\left(801 \mathrm{~kg} \mathrm{ha}^{-1}\right)$ and straw yield $(1735 \mathrm{~kg}$ $\mathrm{ha}^{-1}$ ) under the panchagavya $4 \%$ in the present investigation.

Further, the benefit cost ratio was decreased due to application of lower and higher doses of panchagavya because effectiveness of panchagavya at 2\%, 6\%, $8 \%$ and $10 \%$ panchagavya and indigenous panchagavya $2 \%$ was less enhancing yield attributes and yield as compared to panchagavya $4 \%$.

Similar finding were also observed in blackgram by Somasudaram et al., 2003 and in Abelmoschus esculents by Rajesh and Kaliyamoorthy, 2013. The higher net return due to application of panchagavya at branching + flowering stage could be explained on the basis of increased seed and straw yield under the application of panchagavya at both branching + flowering stages in the present investigation. Similar findings were also observed in groundnut (Choudhary et al., 2014). Similarly, Kumawat et al., (2009) also reported that application of panchagavya at both branching + flowering stages resulted in significantly higher net return ( $₹ 55,376 \mathrm{ha}^{-1}$ ) as well as $\mathrm{B}$ : C ratio (2.66) over application of panchagavya either at branching or flowering.

\section{References}

Choudhary, K.M., Patel, M.M. and Pagar, R.D. 2014. Effect of foliar application of panchagavya and leaf extrects of endemic plants on groundnut (Arachis hypogaea L.). Agricultural Research Communication Centre, 37(2): 223 226.

Emily, A.C.S., 2003. Standardization of organic production packages for Withania somnifera Dunal. M.Sc. Thesis, Tamil Nadu Agricultural University, Coimbatore.

IIPR, 2015. http:www.iipr.res.in

Kanimozhi, B., 2004. Effect of organic manures and biostimulants on productivity and quality of brahmi (Bacopa monnieri L.). M.Sc. (Horti.) Thesis, Tamilnadu Agricultural University, Coimbatore-3, India.

Kannaiyan, K., 2000. Biofertilisers- Key factors in organic farming. The Hindu Survey of Indian Agriculture, pp: 165173.

Kumawat, R.N., Mahajan, S.S. and Mertia R.S. 2009. Growth and development of Groundnut (Arachis hypogaea) under foliar application of panchagavya and leaf extracts of endemic plants. Indian Journal of Agronomy, 54(3): 324-331.

Mudigora, S., and Balikai, R.A. 2009. Evaluation of plant products in combination with cow urine and panchagavya against sorghum shoot fly (Atherigona soccata Rondani). Karnataka Journal of Agriculture Science, 22(3-Spl. Issue): 618-620.

Natarajan, K., 2002. Panchagavya-A Manual. Other Indian Press, Mapusa, Goa, India, pp: 333.

Perumal, K., Praveena, K., Stalin, V. and Janarthanam, B. 2006. Assessment of selected organic manures as plant growth hormones and their impact on the growth attributes of Allium cepa 
Lin. Current Science, 8: 46-51.

Rajesh, M., and Kaliyamoorthy, J. 2013. Changes in morphological, biochemical and yield parameters of Abelmoschus esculents (L.) Moench due to panchagavya spray. International Journal of Modern Plant \& Animal Sciences, 1(2): 82-95.

Sangeetha, V., and Thevanathan, R. 2010. Effect of panchagavya on nitrate assimilation by experimental plants. Journal of American Science, 6(2): 7682.

Selvaraj, N., 2003. Report on Organic Farming at Horticulture Research Station, Tamil Nadu Agricultural University, Ooty. pp: 2-5.

Sharma, O.P., Bambawale, O.M., Gopali, J.B., Bhagat, S., Yelshetty, S., Singh, S.K., Anand, R. and Singh, O.P. 2011. Field Guide Mungbean \& Urdbean, National Centre for Intergrated Pest Management, New Delhi, India. pp. 40. Somasundaram, E., Mohamed, M., Manullah,
A.,
Thirukkumaran,

Chandrasekaran, R., Vaiyapuri, K. and Sathyamoorthi, K. 2007. Biochemical changes, nitrogen flux and yield of crops due to organic sources of nutrients under maize based cropping system. Journal of Applied Science Research, 3(12): 1724-1729.

Somasundaram, E., Sankaran, N., Meena, S., Thiyagarajan, T.M., Chandaragiri, K. and Panneerselvam, S. 2003. Response of greengram to varied levels of panchagavya (organic nutrition) foliar spray. Madras Agriculture Journal, 90(1-3): 169-172.

Swaminathan, C., Swaminathan, V. and Vijayalakshmi, K. 2007. Panchagavya Boon to organic farming, International Book, Distributing Co., Lucknow.

Yadav, B.K., and Lourdraj, C.A. 2006. Effect of organic manures and panchagavya spray on yield attributes and economics of rice (Oryza sativa). Crop Research, 31: $1-5$.

\section{How to cite this article:}

Gopal Lal Choudhary, S.K. Sharma, Kendra Pal Singh, Sanju Choudhary and Bazaya, B.R. 2017. Effect of Panchagavya on Growth and Yield of Organic Blackgram [Vigna mungo (L.) Hepper]. Int.J.Curr.Microbiol.App.Sci. 6(10): 1627-1632. doi: https://doi.org/10.20546/ijcmas.2017.610.195 